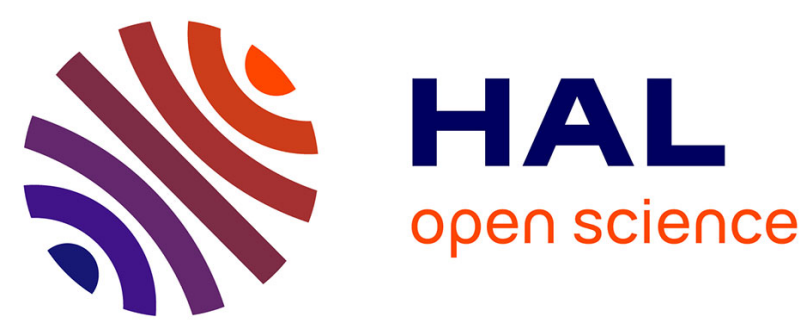

\title{
IMPLEMENTATION OF GAMIFICATION STRATEGIES FOR THE ENHANCEMENT OF DIGITAL COMPETENCES
}

Angel Torres-Toukoumidis, Mario Mäeots

\section{- To cite this version:}

Angel Torres-Toukoumidis, Mario Mäeots. IMPLEMENTATION OF GAMIFICATION STRATEGIES FOR THE ENHANCEMENT OF DIGITAL COMPETENCES. 13th International Technology, Education and Development Conference, Mar 2019, Valencia, Spain. pp.9510-9518, 10.21125/inted.2019.2356 . hal-02392225

\section{HAL Id: hal-02392225}

\section{https://telearn.archives-ouvertes.fr/hal-02392225}

Submitted on 3 Dec 2019

HAL is a multi-disciplinary open access archive for the deposit and dissemination of scientific research documents, whether they are published or not. The documents may come from teaching and research institutions in France or abroad, or from public or private research centers.
L'archive ouverte pluridisciplinaire HAL, est destinée au dépôt et à la diffusion de documents scientifiques de niveau recherche, publiés ou non, émanant des établissements d'enseignement et de recherche français ou étrangers, des laboratoires publics ou privés. 


\title{
IMPLEMENTATION OF GAMIFICATION STRATEGIES FOR THE ENHANCEMENT OF DIGITAL COMPETENCES
}

\author{
Angel Torres-Toukoumidis ${ }^{1}$, Mario Maeöts ${ }^{2}$ \\ ${ }^{1}$ Universidad Politécnica Salesiana (ECUADOR) \\ ${ }^{2}$ University of Tartu (ESTONIA)
}

\begin{abstract}
Transforming the learning process through strategies and tools dedicated to reinforcing experiences, producing commitment, unifying tasks and being fun and persuasive will generate changes in the particular needs of the educational context. In fact, gamification is presented as one of the catalysts of educational potential based on the application of play elements affecting motivation and knowledge apprehension. This research aims to deepen in the suitability of incorporating gamification on the learning process for que acquisition of digital skills. Thus, in this research is examined the disposition of gamification within the global framework of references to digital skills [1] organized into 7 areas and subdivided into 26 competencies: browsing, searching and filtering data, information and digital content; evaluating data, information and digital content; managing data, information and digital content; Interacting through digital technologies; sharing through digital technologies; engaging in citizenship through digital technologies; collaborating through digital technologies; netiquette; managing digital identity; developing digital content; integrating and re-elaborating digital content; copyright and licenses; programming; protecting devices, protecting personal data and privacy; protecting health and well-being; protecting the environment; solving technical problems; identifying needs and technological responses; creatively using digital technologies and identifying digital competence gaps; computational thinking; Operating specialized digital technologies for a particular field; Interpreting and manipulating data, information and digital content for a particular field. The methodology used is based on the application of a questionnaire to 50 experts in educational technologies from Europe and Latin America, obtaining as a result that there is greater convenience in the implementation of gamification for the development of the following digital competencies: collaborating through digital technologies, managing digital identity, programming, engaging in citizenship through digital technologies, sharing through digital technologies and protecting health and well-being. In conclusion, it is evident that the use of gamification for the development of digital competencies is mainly focused on the areas of safety, communication and collaboration. It is therefore recommended to formalize designs of gamification interfaces that address these issues.
\end{abstract}

Keywords: Gamification, digital literacy, Delphi method, interaction, digital competences.

\section{INTRODUCTION}

The development of the digital ecosystem and new trends in information consumption has involved the formulation of new literacies with the aim of facilitating the acquisition of a set of skills, knowledge and attitudes, that people need in order to function within the Information Society. These include media, informational and digital literacy, each contributing to the democratization of knowledge and the need to cope with the mass emergence of ICTs. Precisely, media literacy has been oriented towards the critical formation of new audiovisual content transmission systems [2], while information literacy encompasses knowledge, practices and skills aimed at the use of new tools for the recovery and handling of information conditioned by the personal, institutional and social context [3]. Finally, digital literacy, the object of this research, is presented as a set of competencies aimed at developing instrumental skills, seeking, selecting, organizing, using, applying and evaluating information, effectiveness and ability to share, creativity and problem solving, security, identity, in short, it is based on the use of technology, critical understanding and creation and communication of digital content [4]. The new current technological scenarios towards which contemporary education is directed, make literacy no matter how elementary it is shown, whether it has to be digital or multimedia. Meanwhile, valuing teacher recognition and the progressive implementation of digital literacy in curricular design, it has meant the incorporation of a multiplicity of pedagogical techniques and strategies aimed at its apprehension, among which flipped classroom [5], project-based learning [6], cooperative learning [7], problem-based learning [8], gamification [9], among others. 
As for gamification, a technique analyzed in our research, it is defined as the use of game design elements in non-game contexts [10]. Although it is the best known and least explicit definition of all, in which it is omitted to delve into the particularities of the game design elements and their purpose. For its part, another of the most popular definitions within the academic field states that "Gamification is using game-based mechanics, aesthetics, and game thinking to engage people, motivate action, promote learning, and solve problems" [11] mentioning both the elements of game design and the functions of gamification. Under this context, gamification is based on a series of principles, which in this particular case visualize the six principles of user-oriented efficiency [12].

According to this analysis, any gamification process needs to specify a set of principles that efficiently guide the user experience. This is the only way to materialize a set of phases that satisfy the process:

1 Freedom of choice: Give the user the freedom to act voluntarily, allowing them to deactivate functions and participate in the gamification experience.

2 Benefits and Meanings: The influence of gamification must be relevant to both creators and users, through components that motivate them. Otherwise, the use of the system will not produce any influence, therefore, no benefits will be obtained.

3 Personalized experience: The system must act on different user profiles to trigger acts that demonstrate general acceptance.

4 Long-term interaction: Interactions change. Here it is important to consider motivational theories.

5 Unwanted side effects. Inducing stress, giving the feeling of lack of credibility and privacy, subjectivity with rewards, are factors that can play against gamification systems.

6 Legal and ethical issue: There is a legal context about data, privacy and user interests that must be respected.

These principles contribute to the possibility of issuing a gambling process that has as its priority the safeguarding of the interests of those who participate towards a common goal. Basically, gamification occupies two variables within its principles that allow the creation of specific emotional experiences in the participants:

1 Interaction: Also defined as feedback. Basically, it is about participants communicating and receiving a response to their actions. Regardless of whether it is done with other players or with artificial intelligence, the gambling process has to incorporate the exchange of information.

2 Motivation: From it comes the fun, the commitment of the players for an activity, the entertainment, the freedom of choice. Motivation is part of the human cognitive process that stimulates learning and, therefore, the ability to connect with an activity. Motivation is and must be a necessary and prevailing element in the design of the gambling process.

\subsection{Gamification in education}

According to the results of the application of gamification in the educational context, it is considered that effectively, the transformation of the learning process through strategies and tools dedicated to reinforce experiences, produce commitment, unify tasks and that in turn is fun and persuasive has generated positive changes in the particular needs of the participants [13].

With respect to the fields of study, gamification began to be applied within the field of informatics and information technologies [14], and progressively there was also an incursion into disciplines derived from social sciences such as psychology [15] or those derived from experimental sciences, including mathematics and biology [16].

Similarly, incorporating gamification into learning has involved the formation of three particular approaches. Therefore, structuring ideas on this subject can be summarized as follows: entrepreneurial, empirical and theoretical.

- Business: Projects based on a freemium business idea, adding game elements to motivate participants and increase profitability: Khan Academy, Coursera. 
- Empirical: Field research related to playing elements in education, in which it is possible to measure the usefulness of gamification components in the educational services provided [17], new guidelines are also proposed based on the results of gamification experiences [18].

- Theoretical: Conceptualizations [19], models [20] and strategies [21] linked to education are taken into account, coinciding in the educational potential of play elements to change behavior and promote learning.

Indeed, gamification is a practical system that provides quick solutions with which the user progressively learns through a rewarding experience [22]. In addition, in the educational context, gamification is kept on a path of growth and experimentation predisposed in the different learning modalities, including the presence-based, blended and online modalities, with the purpose of motivating the apprehension of knowledge through the change of attitude in people's behavior [23].

\subsection{Gamification in digital literacy}

The emergence of virtualization, technological literacy, and the need to deepen knowledge has implied the extension of tools that promote digital skills in students in order to train in a collaborative way in problem solving. Among these tools, gamification classification is presented from the perspective of pedagogical renewal and updating, being a relatively new concept within the teaching-learning theme produced in parallel with the development of new technologies. The link between gamification and digital literacy, is proposed from two approaches, in the first gamification and leisure activities has been used as a tool to establish pedagogical strategies approaching users towards the acquisition of digital and informational skills [24] both for secondary students [25] and higher education teachers [26], specifically this link has facilitated the understanding of lexical and mnemonic principles of digital grammar, digital navigation, network operation, determination of the communicational environment and critical evaluation of content [27].

While in the second approach, gamification and leisure activities are proposed as an object of study in digital literacy, that is to say, games form part of the current technological ecosystem in which the training of users in the knowledge society has an impact. Meanwhile, recognizing that interaction with playful platforms generates an influence on players when determining ways of thinking and affecting cognitive skills [28], these must be taken into account in the assessment and promotion of digital competences.

In order to limit the variables corresponding to the link between gamification and digital literacy, the first approach has been predisposed towards the use of gamification strategies to promote the teaching of digital competences, thus building the solid bases for their formal integration.

\section{METHODOLOGY}

The general objective of this study is to analyze the suitability of incorporating gamification on the learning process for the acquisition of digital skills. The following specific objectives have been articulated:

- Reviewing the disposition of gamification within the global framework of references to digital skills

- Evaluating the convenience of the implementation of gamification for the development of digital competences according to educational technologies experts.

For the first specific objective it is worth mentioning that although there are multiple frameworks aimed at developing digital literacy competencies [29], [30] [31], the choice of the Global Framework of Reference on Digital Literacy Skills [1] is justified by its current validity when it was published in 2018 and because it is a global study carried out by UNESCO, a supranational organization legitimized by 195 countries. This framework is organized in 7 areas and 26 competencies: 
Table 1. UNESCO Digital Literacy Global Framework [1]

\begin{tabular}{|c|c|}
\hline Area & Competences \\
\hline \multirow[t]{2}{*}{ Devices and software Operations } & Physical operations of digital device \\
\hline & Software operations in digital device \\
\hline \multirow[t]{3}{*}{ Information and data literacy } & Browsing, searching and filtering data, information and digital content \\
\hline & Evaluating data, information and digital content \\
\hline & Managing data, information and digital content \\
\hline \multirow[t]{6}{*}{ Communication and collaboration } & Interacting through digital technologies \\
\hline & Sharing through digital technologies \\
\hline & Engaging in citizenship through digital technologies \\
\hline & Collaborating through digital technologies \\
\hline & Netiquette \\
\hline & Managing digital identity \\
\hline \multirow[t]{4}{*}{ Digital content creation } & Developing digital content \\
\hline & Integrating and re-elaborating digital content \\
\hline & Copyright and licenses \\
\hline & Programming \\
\hline \multirow[t]{4}{*}{ Safety } & Protecting devices \\
\hline & Protecting personal data and Privacy \\
\hline & Protecting health and well-being \\
\hline & Protecting the environment \\
\hline \multirow[t]{5}{*}{ Problem-solving } & Solving technical problems \\
\hline & Identifying needs and technological Responses \\
\hline & Creatively using digital technologies \\
\hline & Identifying digital competence gaps \\
\hline & Computational thinking \\
\hline \multirow[t]{2}{*}{ Career-related competence } & Operating specialised digital technologies for a particular field \\
\hline & $\begin{array}{l}\text { Interpreting and manipulating data, information and digital content for } \\
\text { a particular field }\end{array}$ \\
\hline
\end{tabular}

The framework used by UNESCO is based on The Digital Competence Framework 2.0 [32] adding 2 new areas each with 2 new competencies, specifically devices and software operations and careerrelated competence. Both are correlated. The first of these, although approaching information literacy, aims to ensure that the user generally identifies and knows how to use hardware and software, recognizing the advantages of their operability, while career-related competence refers to the use and interpretation of digital tools within each specialized field.

As for the second objective, 50 experts in educational technologies were selected, the experts selected to answer the questionnaire are doctors and researchers from the departments of applied technology education and communication belonging to the University of Huelva-Spain-, University of Cantabria-Spain-, University of Coimbra-Portugal-, Università di Torino-Italy-, Katholieke Universiteit Leuven-Belgium-, Saint Cloud State University-United States-, Tecnológico de Monterrey-Mexico-, Universidad Politécnica Salesiana-Ecuador-, Universidad Luis Amigó-Colombia, Universidad de la Habana-Cuba- and Universidad Metropolitana-Venezuela to the convenience of implementing gamification for the development of digital competences. In the first instance, to determine the number of experts selected, one of the most cited researches in media literacy [33] was used as a reference, which likewise incorporates 50 experts from Europe and America to construct the dimensions and indicators of this subject. Under this heading, the 50 experts questioned answered 27 questions based on a 3-point Likert scale questionnaire about the degree of agreement: 3-agree; 2: 
unsure/uncertain/neutral; 1-disagree. In total, 26 questions were about the implementation of gamification as a strategy for the development of each of the digital competencies, while one question, and in this case the last of the 27, referred to the degree of agreement on the use of the Global Framework of Reference on Digital Literacy Skills [1] to connect gamification with digital literacy. It should be noted that next to each question a blank space was proposed for experts to optionally express their views on the link between gamification literacy and each competency.

Table 2. Example of the question's items

\begin{tabular}{|c|c|c|c|}
\hline Indicators & 3-agree & 2-unsure/uncertain/neutral & 1-disagree \\
\hline \multicolumn{2}{|c|}{ 1. Information and data literacy } & \\
\hline $\begin{array}{c}\text { 1.1 Browsing, searching and } \\
\text { filtering data, information and } \\
\text { digital content with gamification }\end{array}$ & & & \\
\hline $\begin{array}{c}\text { 1.2 Evaluating data, information } \\
\text { and digital content with } \\
\text { gamification }\end{array}$ & & & \\
\hline $\begin{array}{c}\text { 1.3 Managing data, information } \\
\text { and digital content with } \\
\text { gamification }\end{array}$ & & & \\
\hline
\end{tabular}

The questionnaire was applied from October 15 to November 15, 2018 to experts from Spain, Portugal, Italy, Belgium, United States, Mexico, Ecuador, Colombia, Cuba and Venezuela, generating the following contributions.

\section{RESULTS}

After evaluating the results obtained, it should be mentioned that there is a high degree of agreement among experts in linking the Global Framework of Reference on Digital Literacy Skills [1] with gamification classification, thus obtaining a positive response of $98 \%$ of those surveyed. Only one of the experts commented on the need to make a comparison between the different digital literacy frameworks analyzing the suitability of applying gamification in digital competences. In spite of this, the competencies that received the greatest degree of agreement regarding the use of gamification strategies for their teaching are the following: collaborating through digital technologies, managing digital identity, programming, engaging in citizenship through digital technologies, sharing through digital technologies, and protecting health and well-being.

\subsection{Collaborating through digital technologies}

The $92 \%$ of the experts surveyed agree on the suitability of gamification and use digital tools and technologies for collaborative processes and for co-construction and co-creation of resources and knowledge. Some of the comments made show that gamification enhances teamwork and group cohesion through proposed challenges and feedback of the solutions obtained. Likewise, gamification offers the opportunity to establish networks of collaboration and consensual decision making motivated by a group reward.

Basically, there are a series of gamification platforms that invite collaborative work, among which are: Duolingo, Tango Card, LevelEleven and so on.

\subsection{Managing digital identity}

Second, $86 \%$ of experts believe that gamification affects competition aimed at creating and managing one or multiple digital identities, to be able to protect one's own reputation, to deal with the data that one produces through several digital tools, environments and services. The gamification grants the advantage of motivating the personalization and the creation of avatars fulfilling the search to reach a social status and a representation of the person with the purpose of promoting the sensation of being inside a social circle.

Among the gamification experiences that incorporate the idea of identity are GamEffective, Classcraft, Byju's and Bounty Tasker. 


\subsection{Programming}

Considering that programming is inherently embedded in gamification [34]. In this case, $82 \%$ of the experts agree to add gamification in this process, in fact, there are already experiences [35] in which the use of gamification mechanics for teaching programming is exhibited by applying the PBL system (points, badges and leaderboards) together with levels and restrictions that facilitate student motivation.

As for programming, gamification can be seen in Treehouse, Codecademy, Code Hunt, Dungeons and Developers, Ruby Warrior, Hack n Slash.

\subsection{Engaging in citizenship through digital technologies}

The $78 \%$ of experts recognize that gambling can boost participation in society through the use of public and private digital services. To seek opportunities for self-empowerment and for participatory citizenship through appropriate digital technologies. Among the gaming elements promoted by gamification in this context are feedback, levels, reward systems, challenges and random elements [36]. In short, gamification allows for the configuration of an active citizenship that makes decisions and is actively involved in public policy programs geared towards digital technologies, especially young people, who will face the orientation of future public policies.

Regarding the following indicator, the commitment of citizens through gambling can be observed in the following experiences that combine e-participation: Love Your City!, OldWeather, DoGood [38], Digitalcitizen, etc.

\subsection{Sharing through digital technologies}

Admitting that this competition concentrates on sharing data, information and digital content with others through appropriate digital technologies acting as an intermediary, to know about referencing and attribution practices. The $74 \%$ accept their link with gamification, essentially arrange alliances and meetings for common purposes, build teams, support interaction in chats, appoint ambassadors, influencers who sponsor good practices and finally are awarded rewards for inviting and sharing actions that could benefit the use of digital technologies.

The new technologies have facilitated the exposure and the interweaving of contents between digital platforms, which is why the gamification is evident in applications such as: Evoq Engage, Rise and Playlyfe.

\subsection{Protecting health and well-being}

The problems caused by the excessive use of new digital technologies, among which are visual problems, obesity, depression among others can be prevented through the use of gamification [37]. The $72 \%$ of the experts agree with this premise, some of them have commented that gambling stimulates physical activity and breaks with sedentarism, they even express that gambling has been applied in preventive campaigns producing greater interest on the part of society and changes in behavior.

Finally, the protection of health and well-being has also been specifically highlighted in gamma applications, among which are: Loseit!, Mango Health, CaféWell, Blue Shield California, Ayogo, Reflexion Health, Cohero Health, Pact, HubBub, Cog Cubed, Fitocracy, Zombie Run! among others.

\section{CONCLUSIONS}

The information addressed our research demonstrate that safety, communication and collaboration are the areas of digital literacy that have the greatest attachment to learning with gamification strategies. In addition, the interactive trend produced by the incorporation of gamification for the development of digital competencies is seen as an opportunity to generate an active engagement learning through a constructivist approach. [39].

The use of multiple mechanics from game elements tends to create greater motivation among students [40], thus impacting on the acquisition of digital skills. In sum, this study has achieved the 2 specific objectives through the questionnaire applied to the 50 experts. The first of the analyzed objectives states that the use of frameworks can be used to determine the gamification disposition. In 
the second instance, although the $26(100 \%)$ digital literacy competencies are over 50\% agreed for the implementation of gamification, there are 6 competencies that are over $70 \%$ : collaborating through digital technologies, managing digital identity, programming, engaging in citizenship through digital technologies, sharing through digital technologies, and protecting health and well-being, which are more suitable for the potential application of gamification. We recommend that future researchers apply gamification empirically in each of the above-mentioned competencies in order to measure its effect on digital literacy.

\section{ACKNOWLEDGEMENTS}

This work has been prepared within the framework of Alfamed (Euro-American Interuniversity Network for Research in Media Competencies for Citizenship), with the support of the Coordinated R\&D\&I Project "Media Competencies of Citizens in Emerging Digital Media (Smartphones and Tablets): Innovative practices and educommunicative strategies in multiple contexts" (EDU2015-64015-C3-1-R) (MINECO/FEDER), and the "Media Education Network" of the State Program for Scientific ResearchTechnical Excellence, State Subprogram for Knowledge Generation (EDU2016-81772-REDT), financed by the European Regional Development Fund (ERDF) and the Ministry of Economy and Competitiveness of Spain and the first Games Laboratory of Ecuador GameLab UPS.

\section{REFERENCES}

[1] N. Law, D. Woo, J. de la Torre and K Wong, A Global Framework of Reference on Digital Literacy Skills for Indicator 4.4. 2. Canada: UNESCO Institute for Statistics, 2018

[2] J. M. P Tornero, "La sociedad multipantallas: retos para la alfabetización mediática," Comunicar: Revista científica iberoamericana de comunicación y educación, vol.16, no.31, pp. 15-25, 2008.

[3] B. Johnston and S. Webber, "Como podríamos pensar: Alfabetización informacional como una disciplina de la era de la información," Anales de documentación, vol. 10, 2007.

[4] R. Avello Martínez, et al., "Evolución de la alfabetización digital: nuevos conceptos y nuevas alfabetizaciones," Medisur, vol.11, no.4, pp. 450-457, 2013.

[5] I. García, N. Castro-Lemus and P. Toledo-Morales, "Las flipped classroom a través del smartphone: efectos de su experimentación en educación física secundaria," Prisma Social: revista de investigación social, no. 15, pp. 296-351, 2015.

[6] A. Burdick, and H. Willis, "Digital learning, digital scholarship and design thinking," Design Studies vol.32, no.6, pp. 546-556, 2011

[7] F. Jun, and J. Pow. "Fostering Digital Literacy through Web-based Collaborative Inquiry Learning--A Case Study," Journal of Information Technology Education, vol. 10, pp:57-71: 2011.

[8] J. Voogt, Joke, O.Erstad, C.Dede, and P. Mishra, "Challenges to learning and schooling in the digital networked world of the 21st century," Journal of computer assisted learning, vol. 29, no. 5, pp 403-413, 2013.

[9] T. Kingsley and M. Grabner-Hagen, "Gamification," Journal of Adolescent \& Adult Literacy, vol. 59, no.1, pp. 51-61, 2015.

[10] Deterding, Sebastian, et al. "From game design elements to gamefulness: defining gamification," Proceedings of the 15th international academic MindTrek conference: Envisioning future media environments. ACM, 2011.

[11] K. Kapp, The gamification of learning and instruction: game-based methods and strategies for training and education. EEUU: John Wiley \& Sons, 2012.

[12] F. Marache and E. Brangier, "Perception of gamification: Between graphical design and persuasive design," International Conference of Design, User Experience, and Usability. Springer, Heidelberg, 2013.

[13] J. Koivisto and J. Hamari, "Demographic differences in perceived benefits from gamification," Computers in Human Behavior vol.35, pp. 179-188, 2014. 
[14] D. Dicheva and C. Dichev, "Gamification in Education: Where Are We in 2015?," E-Learn: World Conference on E-Learning in Corporate, Government, Healthcare, and Higher Education, AAACE, 2015.

[15] S. Estrada, "El perfil del estudiante: Nuevo desafío para la educación puertorriqueña," Revista Puertorriqueña de Psicología, vol. 25, no.2, pp. 414-416, 2014.

[16] F. Lubis, Y. Rosmansyah, and S. Supangkat, "Math workout series: Enhancing learning application with gamification," Information Technology Systems and Innovation (ICITSI), International Conference, IEEE, 2014.

[17] J. Hamari, "Transforming homo economicus into homo ludens: A field experiment on gamification in a utilitarian peer-to-peer trading service," Electronic commerce research and applications, vol.12, no.4, pp.236-245, 2013.

[18] J. Simões, R. Redondo, and A. Vilas, "A social gamification framework for a K-6 learning platform," Computers in Human Behavior, vol. 29, no.2, pp. 345-353, 2013.

[19] J. Lee, and J. Hammer, "Gamification in Education: What, how, why bother?," Academic Exchange Quarterly, vol.15, no.2, pp.1-5, 2011.

[20] J. Kim, and W. Lee, "Dynamical model for gamification of learning (DMGL)," Multimedia Tools and Applications, vol.74, no.19, pp.8483-8493, 2015.

[21] C. Holman, S. Aguilar, and B. Fishman. "GradeCraft: What can we learn from a game-inspired learning management system?," Proceedings of the third international conference on learning analytics and knowledge, ACM, 2013.

[22] J. Lee, et al., "GREENIFY: A real-world action game for climate change education," Simulation \& Gaming, vol. 44, pp.349-365, 2013.

[23] L.M. Romero-Rodríguez, A. Torres-Toukoumidis, and I. Aguaded, "Ludificación y educación para la ciudadanía. Revisión de las experiencias significativas," Educar, vol. 53, no. 109-128, 2017.

[24] J. Rozo, et al., "Estrategias de gamificacón aplicadas al diagnóstico de la incorporación pedagógica de las TIC en una comunidad académica," Cultura Educación y Sociedad, vol.4, no.1, pp. 55-74, 2013.

[25] J. Rioja, D. Besora, and M. Vizern, "Experiencia de gamificación en Secundaria en el Aprendizaje de Sistemas Digitales," Education in the Knowledge Society, vol. 18, no. 2, 85-105, 2017.

[26] M. Agreda Montoro, M. Hinojo Lucena, and J. Sola Reche. "Diseño y validación de un instrumento para evaluar la competencia digital de los docentes en la Educación Superior española," Pixel-Bit: Revista de Medios y Educación, vol. 49, pp. 39-56, 2016.

[27] M. R. Rodriguez, "Gamificación de la alfabetización digital en mayores según los estilos de aprendizaje y actividades polifásicas," Journal of Learning Styles, vol 11 no. 22, pp. 179-215, 2018.

[28] Y. Eshet, "Digital literacy: A conceptual framework for survival skills in the digital era," Journal of educational multimedia and hypermedia, vol. 13, no 1, pp. 93-106, 2004.

[29] A. Martin, "DigEuLit-a European framework for digital literacy: a progress report," Journal of eLiteracy, vol. 2, no. 2, pp. 130-136, 2005.

[30] M. Neumann, G.Finger and D. Neumann, "A conceptual framework for emergent digital literacy," Early Childhood Education Journal, vol. 45, no.4, pp. 471-479, 2017.

[31] R. Reynolds, "Defining, designing for, and measuring "social constructivist digital literacy" development in learners: a proposed framework," Educational Technology Research and Development, vol.64, no.4, pp. 735-762, 2016

[32] R. Vuorikari, Y. Punie, S. Carretero Gomez, and G. Van den Brande, DigComp 2.0: The Digital Competence Framework for Citizens. Update Phase 1: The Conceptual Reference Model. Luxembourg: Office of the European Union, 2016. 
[33] J. Ferrés, and A. Piscitelli, "La competencia mediática: propuesta articulada de dimensiones e indicadores," Comunicar: Revista Científica de Comunicación y Educación, vol. 19, no. 38, pp. 75-82, 2012.

[34] B. Burke, Gamify: How gamification motivates people to do extraordinary things. Reino Unido/ Routledge. 2016

[35] C. González González, and A. Mora Carreño, "Técnicas de gamificación aplicadas en la docencia de Ingeniería Informática," ReVisión, vol. 8, no.1, pp. 29-40, 2015.

[36] Torres-Toukoumidis, Evaluación de políticas públicas con técnicas de gamificación para la educación ciudadana.Huelva/Spain: Universidad de Huelva, 2016.

[37] R. Ahola, et al.,"Gamified physical activation of young men-a Multidisciplinary PopulationBased Randomized Controlled Trial (MOPO study)," BMC public health, vol. 13, no.1, pp.1-8, 2013.

[38] S.Thiel, and P. Fröhlich, "Gamification as motivation to engage in location-based public participation?" in Progress in Location-Based Services, 399-421, EEUU: Springer, 2017.

[39] M. Mäeots, L. Siiman, and M. Pedaste, "Designing Interactive Scratch Content for Future Ebooks," International Conference on Web-Based Learning. Springer, Cham, 2014.

[40] M. Hanus, and J. Fox, "Assessing the effects of gamification in the classroom: A longitudinal study on intrinsic motivation, social comparison, satisfaction, effort, and academic performance," Computers \& Education, vol. 80, pp. 152-161, 2015. 